\title{
A CONTRIBUTION TO THE STUDY OF LONG-CONTINOED
} FEVRRS.'

\author{
Br Herbert C. MoffitT, M.D.,

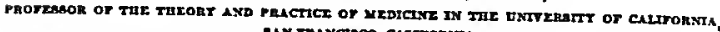 \\ sux muxciaco, ceinroksu.
}

'Turovar the kindness of Dr. F. H. Humphris, of Honolulu, there was referred to me in July, 1906, a lady of forty-seven years with the following interesting history: There had been no tuberculosis or malignant disense in the family. She had been twice married-the first time at sixteen - and had one child living and well. As a girl, she was said to have had malarin. In 1893 she had heen infected with syphilis, which was treated three months at Arkansas Hot Springs, and again for some weeks in 1900 . For ten years there had been a cough each winter lasting three or four months, annoying mither than serious, and only occasionally keeping her in bed. During these years there hnd been four or five attacks of socalled "la grippe," attended with fever for a few dnys, cough, and aching. In 1895 a curettage was done for some slight utcrine derangement, but there had never been serious pelvic symptoms. In 1898 an acute attack of abdominnl pain was referred to the appendix, and Dr. Murphy, of Chicago, operated later in the yenr and removed an appendix showing slight pathological chnnges.

During 1902 and the first half of 1903 she was very well and travelled extensively. In the latter part of 1903 and the first months of 1904 she had three attacks of sudden, severe abdominat pain. The pain was general throughout the abdomen, colicky, lasted a few hours, and was thought due to eating fruit and drinking mineral water. In Paris, during the summer of 1904, she was tired, nervous, and had little appetite, but felt well during the autumn in St. Louis. A little later, in Chicago, there was fever for a few davs, with headache and aching in the muscles, and she felt badly for a month. The usunl bronchitis kept ber rather miserahle during the winter of 1904 and 1905 in Paris, and an attack called "la grippe" confined ber to the house for a few days in March. In the sumner months, in New York, she felt tired, had very little appetite, and was said to have liver trouble. She was much better a little later in Cannda and the Northrest, and felt perfectly well when she sailed for Honolulu in September, 1905. The patient had always been a great traveller. She spent 1902 in France, Italy, and Austrin. In 1903 she was in Japan, Honolulu, Mexico, France, and Spain; in 1904 in Italy, the Riviera, Greece, Turkey, the Meditermean and Egypt.

\footnotetext{
1 Read at a meeting of the Association nf Amerienn Muysicians, Wanhinghan, D. C., May 7,8, anil $0,100 \%$.
} 
The present illness began on the steamer two days before reaching Honolulu, in September, 1905. There was intense muscular soreness, considerable pain in the joints, and fever lasting a week. She was then perfectly well for two weeks until pain and fever recurred on the trip to Australia. This attack lasted a week, and was followed by an apparent complete recovery. After two weeks, bowever, sbe had recurrence of the familiar prostration and fever and was under the care of Dr. Hooper, of Melbourne, for a time. A blood examination, made October 24,1905 , by Dr. F. W. Wilkinson, showed red corpuscles, 4,600,000; white corpuscles, 8000 ; hemoglobin, 90 per cent.; no malarial parasites; a distinct increase of large mononuclear leukocytes.

- After this attack she felt well, and was able to travel considerably about Australia. From October to February there were three similar periods of pyrexia, but sbe was not confined to bed. In February there was a severe attack in Rotorua lasting a week, during which joint and muscle pains were intense. Since that time there bas been absolutely no pain, and recurrent pyrexia bas been the sole feature (see tbe accompanying chart).

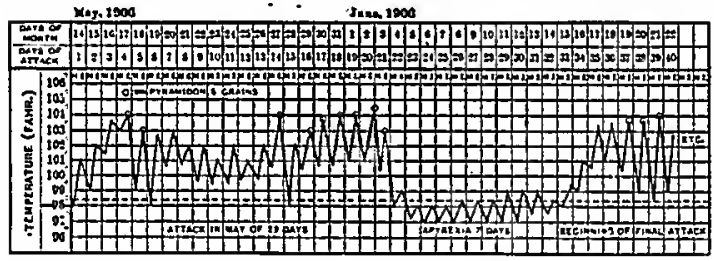

The course of the disease to August 28, 1906, wben the patient died, is given in the subjoined table.

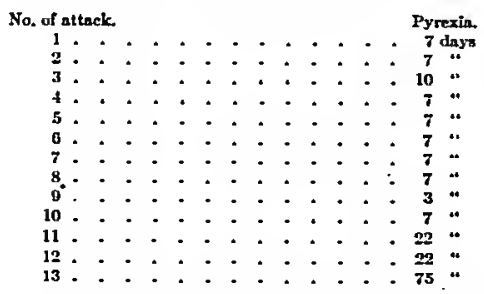

\begin{tabular}{|c|c|}
\hline \multirow{2}{*}{\multicolumn{2}{|c|}{$\begin{array}{l}\text { Apyzetic interval. } \\
\text { (Approximate.) } \\
\text { Ifudays }\end{array}$}} \\
\hline & \\
\hline \multicolumn{2}{|c|}{ nut known } \\
\hline$" 4$ & \\
\hline 4 & $\bullet$ \\
\hline 44 & " \\
\hline \multicolumn{2}{|c|}{10 dnys } \\
\hline 10 & $"=$ \\
\hline 14 & 4 \\
\hline 14 & * \\
\hline 14 & ** \\
\hline 0 & 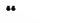 \\
\hline
\end{tabular}

During the first attacks aching in the muscles and joints was intense, and suggested dengue. In the intervals bealth was perfect, 
and the patient travelled, ate well, and nothing suggested a return of the trouble until fever recurred. The temperature rose rapidly, but not abruptly, and fell by lysis; during the intervals, when measured, it was slightly subnormal. With the recurrence of temperature, there was increased constipation, some bloating, malaise, and, in the later periods, great prostration, occasional chills, and great discomfort from sweating. Under Dr. Humphris' observation, the pulse was of good quality, from 74 to 90 ; quinine did not affect the temperature, and made the nerrous symptoms worse; pyramidon, in 5-grain doses, was found to give much relief, with a quick drop in temperature and profuse sweating. Until July there was no evidence of cachexia, ind the absence of symptoms and signs was in striking contrast to the monotonous daily temperature.

When seen July 20, the patient had a peculiar earthy color, not unlike that seen in liver abscess. There was fever of a marked remittent, intermittent type. Shaking chills occurred every three or four days. At the height of temperature, there was great restlessness, sometimes mild delirium, but no pain. Pyramidon was occasionally required to control temperature; 5 grains would be quickly followed by a drop of $3^{\circ}$ to $5^{\circ}$ and a drenching sweat. Even without pyramidon, profuse sweating was frequent.

There were slight changes at both apices, but no evidence of an active process. The chief thing of interest in the thorax examination was the curved linc of liver dulness, reaching to the fourth rib in the mammillary and anterior axillary lines, to the angle of thc scapula and down to the eleventh spine at the vertebral column. Despite the enlargement of the liver upward, which showed beautifully on an $x$-ray plate, there was at no time any evidence of enlargement downwand. The area of splenic dulness was frequently a little large, but the spleen was never palpated in almost daily examinations over a period of four weeks. The heart was markedly dilated, particularly the left ventricle, and there was a systolic murmur over the precondium, with greatest intensity over the base. The pulse was slow in comparison to the temperature, a veraging So to 100 .

The abdomen was considerably distended, not tender, and in the last days a small amount of free fluid could be demonstrated. Superficisl glands could never be palpated, nor were there glands to be felt in the abdomen or by rectum. The follicles of the tonsils and base of the tongue were not enlsrged-in fact the tongue suggested the smooth atrophy of Virchow, but was not positive. There was extreme myosis, which had been noted for some years. The pupillary outline was irregular, and reaction to light was practically absent. There were no fundus changes, and nothing else in the nervous system to suggest syphilis. Pelvic and rectal examination was negative. The urine at different times showed a trace of albumin, and a few hyalin casts. Diazo reaction was constantly present, 
sometimes faint, and again well marked. In the last days urobilin was present in considerable amount, with a trace of bile. The stools were microscopically negative, and contained no occult blood.

Cultures in bouilion, made on two occasions, with blood from puncture of a vein gave no growths. Serum reactions with cultures of typhoid and paratyphoid bacilli, and Micrococcus melitensis were negative in dilutions of 1 to 50 and 1 to 20 . Of principal interest in the blood counts (see the accompanying chart) was the moderate secondary anemia, with marked leukopenia and relative increase in the large mononuclear forms. Some of these cells were distinctly larger than the normal type.

\begin{tabular}{|c|c|c|c|c|c|c|c|c|}
\hline \multirow[b]{2}{*}{ Date. } & \multirow[b]{2}{*}{ Reds. } & \multirow[b]{2}{*}{$\stackrel{2}{E}$} & \multicolumn{5}{|c|}{ Percentage. } & \multirow[b]{2}{*}{ Remarke, } \\
\hline & & & $\begin{array}{l}\text { Pals- } \\
\text { auclear }\end{array}$ & $\begin{array}{l}\text { Sman } \\
\text { mono- } \\
\text { nuclear }\end{array}$ & $\begin{array}{l}\text { Lame } \\
\text { mono } \\
\text { puclear }\end{array}$ & Eooino- & Вв: & \\
\hline October 24,1905 & $1,000,000$ & 8000 & $\cdots \cdot \cdot$ & $\cdots$ & crease. & $\cdots$ & 90 & $\begin{array}{l}\text { No plasmodia. 3rado } \\
\text { by Dr. John F } \\
\text { Whikinon, Mel- } \\
\text { bouroe. }\end{array}$ \\
\hline 2,1906 & $8,800,000$ & 7200 & 78.0 & 21.0 & 1.0 & $\ldots$ & - & $\begin{array}{l}\text { No plasmodis. Yrado } \\
\text { bs Ds. Eumptris, } \\
\text { Bopolvin, T. H. }\end{array}$ \\
\hline Bray 21,1906 & $3,000,000$ & 5800 & 67.0 & 320 & $\ldots$ & 1.0 & & \\
\hline Jaly 21,1900 & $1,116,000$ & 5000 & 88.0 & 8.0 & 9.0 & $\cdots$ & 70 & $\begin{array}{l}\text { Temperature } 1020 \\
\text { sjgot rsatiation } 10 \\
\text { size of red celts }\end{array}$ \\
\hline Jals $\quad 31,1906$ & -... & 3500 & 725 & 120 & 15.5 & ....... & $\cdots$ & $\begin{array}{l}\text { Alter chlll. Temper- } \\
\text { ature } 104^{\circ} \text {. }\end{array}$ \\
\hline July 22,1906 & $1,002,000$ & 2800 & 65.0 & 15.5 & 19.5 & $\cdots . .$. & $\cdots$ & No playmodia. Few \\
\hline Angiest 4. 1506 & $3,100,000$ & 5000 & 79.0 & 9.0 & 18.0 & ...... & 50 & 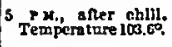 \\
\hline Augual 11, 1906 & $3,2 \pi 2,000$ & 2500 & 80.0 & 9.0 & $11.0 !$ & $m$ & 60 & No nuclealed reds. \\
\hline
\end{tabular}

With the peculiar recurrent pyrexia, the conditions considered in diagnosis were chiefly Malta fever, Hodgkin's disease or lymphosarcoma, syphilis of the liver, and gallstones in the common or hepatic ducts with.catarrhal cholangitis. The aching of joints and muscles in the early periods, the undulant fever, the recent visit to many Mediterranean ports would suggest Maltn fever, but the frequent repetition of attacks and the negative serum reaction decided against it. Serum reactions in this disense are not always unequivocal. ${ }^{2}$

Echinococcus of the liver was suggested by the shape of the right

In army pathologiat of fide experience sent a man to tha hospital wilh lhe diagnosis of Malta fover from tho ardutination test; but the reeurrent fever later cleared up on drainage of an unreconnized empyemn. In another cass with positivo ecrum renction, gonorrheal infection was shown to be the cause of tersperature and of joint symptoms. 
lobe, but the radiogram gave no characteristic pieture, and the ahsence of eosinophilia and leukocytosis spoke against it.

The absence of jaundice was much against a ball-valve calculus in the common duct. The occasional complaint of distress over the liver, with a feeling of distention in the abdomen, suggested the possibility of a calculus in the hepatic ducts, as in the cases of Frerich ${ }^{3}$ and Schmitz. The failure of a polynuclear leukocytosis just after a chill and rapid rise of tcmperature, was decidedly against an infeetive cholangitis. My experience has been that of Pick, that in cases of infeetive eholangitis (of pyelitis and nearly all cases of malignant endocarditis as well), there is a decided polynuclear leukocytosis just after a paroxysm of chill and fever. There may have been a normal count, or a leukopenia, with normal ratio, during the fehrile or afebrilc period before the paroxysm, and the sudden change in the blood picture is most striking.

Despite the characteristic alternating pyrexia, the ahsence of palpable glands and spleen, and of enlarged mediastinal glands, was much against Hodghin's discase or lymphosarcoma limited to the liver; although the cases of Naunyn and Rolleston ${ }^{\top}$ bad lately been brougbt to my mind in reviewing a ease of intermittent hepatic fever."

Naungn mentions the ease of a woman of forty with intermittent fever for some months and paroxysms of elill, fever, and smeating recurring about 4 P.s. daily. There was considerable liver enlargement and an irregular tumor of the left kidney. The patient demanded operation on account of the unsupportable chills and sweating. The left kidney was removed, and contained a sarcomatous mass the size of an apple. The liver appenred normal. The chills and fever ceased, and the patient improved until, after four weeks, the fever recurred. Death oceurred from exhaustion, and at autopsy metastases were found in retroperitoneal nnd medistinal glands, and a large central mass in the liver.

The history of syphilis, the pupillary ehanges, the signs of some liver affection, demanded specific therapy. Mercury was given by inunetions and lypodermically, and iodide was administered up to 6 grams daily in combination with ascending doses of Forvler's solution. There was no improrement at the end of three weeks; the

\footnotetext{
Ieberkrankheiten, Band ii, 405.

1 Berl. Klia. Woch., 1801. 915.

- Zur Diagnoatik der Infekte der Galleavere. Mittheil. aus den Grens, d. MIed. u. Chir. viii, 174; Ueber Intermittirendes Gallenfieber. Deut. Arch. I. klin. Med., Irix, 1.

- Cholelithiasis, S. 69.

Dineases of the Isver, p. 38s; Ibid. p. 152.

- Rolleston in writing of Istmphosarcoma of tbe liver records thas: "Exceptionally the organ is very considerably enlarsed, and if the auperfidel lymphatic glands available for elinical examination aro but litsle affected. the chinieal erpect of the cane, eapecially when there in a hectic tempersture, may sugat bepatic absces, os in a case, under my cart." Arain. "Some years aro a man was uxder my care with a pedunculated mass in the left aroin of many years' etanding, whicb tumed out to be lymphadenoma; he developed a heetis temnerature and considerable enlargement of the liver. The condition was not unlike lenatic abecess, and the question of operation was raised during life."
} 
patient was weaker, slight icterus developed, and moderate ascites could be demonstrated. Operation was demandad by the patient for relief of the intolerable discomfort caused by the temperature and sweating, and an exploratory laparotomy was done hy Dr. Beverly Macilonagle in the hope of finding an abscess, or, as in Israel's case, a gumma that could be reached surgically. On opening the abdomen a moderate amount of blood-stained luid escaped. The liver edge was a little above the costal margin, was irregular, rounded, and tbe liver was studded with wbitisb, irregular nodules the size of a pea or a small marble. A piece of the liver was removed and sent to Dr. William Opbüls for examination. The wound was closed, and the patient sent to bed in fair condition, lut death occurred next day from exhaustion.

The following is Dr. Opbül's report: "Sections show multiplc tumor nodules, which, in the peripbery, consist almost entirely of very large round or oval cells. MIany of these cells show mitotic figures. The central parts of the nodules are made up of somewhat smaller cells, with some connective-tissue fibers between them. No caseation. In the periphery the tumor infiltrates the liver tissue following the course of the lymphatics along the capillaries. No definite alveolar arrangement can he made out in any place. The tumor has the appearance of a sarcoma."

At the autopsy the lungs were found emphysematous, with puck- . ered scars and shrinking at both apices. The beart was flabby, much dilated, the cndocardium normal, the ascending aorta dotted with atheromatous patches. Near the hilum of the right kidney, which was-in normal position, was a large retroperitoneal gland the size of a golf ball. This was the only gland enlarged anywbere in the body, except a few pigmented glands the size of small beans, such as one usually sees ahout the roots of the lungs. The follicles of tbe gastro-intestinal tract were not enlarged. Chiefly remarkable was the enlargement of the dome of the liver, as had been determined clinically; the diaphragm was pushed up to the third rib. The failure of the liver to enlarge downward was explained hy thic puckering of the rounded edges by several deep scars and the presence of several firm adhesions to the anterior abdominal wall-plainly the result of an old luetic process. Great numbers of wbitish nodules studded the right lobe of the liver; there were only five or six in the left lobe. The spleen was not enlarged, 12 by $7 \mathrm{~cm}$.; on section there were three whitish, irregular nodules the size of lima beans similar to the growths in the liver. Microscopically the tumors of the lymph gland, liver, and spleen showed a similar structure to the nodule removed at operation. There was no caseation. Giant cells and eosinophiles were not present. No tubercle bacilli were found in the smears from the gland tumor. The growth would bc best classed, therefore, as a lymphosarcoma.

Retrospectively, it would seem that the attacks of abdominal pain 
in 1904 marked the beginning of the disease, probably in the retroperitoneal gland, and that the fever, general pains, and indefinite symptoms in the bepatic region of the last year signalled the invasion of tbe liver. It is difficult to assign a definite role in etiology to syphilis, nor can the limitation of the malignant process to one lympb gland be in any way explained. Syphilis may perbaps bave rendered the liver less resistant to invasion of the growth. Treatment would probably bave arailed little at any stage of the disease. Large doses of arsenic and specific treatment were given during the last month of life without. effect. $X$-ray treatment and Coley's serum migbt bare been tried in the apyretic intervals. $X$-ray treatment was out of the question while the patient was under my care, owing to the -pyrexis and cachexia; it is, even in afebrilc cases, at times distinctly detrimental.'

Recurrent fever in tuberculous lymphomas, in Hodgkin's disease, in lympbosarcoma or sarcoma of other varieties bas been chronicled in numerous papers: Dr. Musser reviewed the literature, and added two personal cases in a communication to this Association in 1901. Graves mentioned occurrence of the peculiar temperature in some cases of lympbomas before Murchison'sti paper in 1870. Gowers ${ }^{11}$ introduced the name alternating pyrexia in bis article on Hodgkin's disease in Reynold's Practice; Southey (1875) and Sainsbury were among the early English authors recording cases; $\mathrm{Pcl}^{12}$ in 1885, and Ebstein ${ }^{23}$, in 1887, called general attention to the peculiar fever type, and Ebstein thougbt be was describing a ncw clinical entity, which he termed "das chronische Rückfallsfieber." It soon became recognized, however, that recurrent fever is a symptom and not a disease. The papers of Graves, Murchison, Southey, Gowers, Sainsbury, Pel, and Ebstein dealt with Hodglin's disease. In Klein's' $\mathrm{s}^{14}$ case, reported as cirrbosis of the liver and pseudoleukemia with recurrent fever, the history suggests strongly that fever was of the intermittent bepatic variety. Two of Kast's ${ }^{15}$ cases would be classed clinically as Hodgkin's. In a boy of seven, with enlarged glands, spleen, and liver, there were nine periods of pyreria, and toward tbe last a leukocytosis (the kind not described)

\footnotetext{
- In an old tman with reneralived Hodglin's disense. who had previously had periods of pyrexin, a tew x-ray exposures were followed by remitteot fever. which persinted till death some three weeks later. A man ured forty jears bad recurreoce of lymphosareoma io the epleen sod liver six month after a primary tumor in the glands of the right axilla was removed. Four attempts were made at a-ray trestment. Each time, alter three or four thort exposures over the liver and apleen. there would be ebill followed by rapid rise of tempernture to $103^{\circ}$ or $104^{\circ}$. prostration, loss of appetite, and persistence of fever for four or Eve dags.

10 Trans, Path. Boc, Lood., 1570, $2 \times 0.372$.

11 Reynolds' Syntem of Medicine, 1879.

12 Zur Symptomatologie der togenannien Preudoleukrmie Berl. klio. Woch., 1885, 3; Pseudoleukremie oder chronieches Rockdallsfieber. Bert. klin. Woch. 1887, 044.

is Das ehronische Rdekfallsfieber. Best. klin. Woeh., 1857, 565.

11 Fio Fall voo Pacudoleukenio nebat Lebercimhose mit rectrrierendern Fieberverlaut. Bert, ktin. Woch.. I890, 712

is Ueber Rnckfallafieber bei multipler Sarkombilduog.
} 
of 100,000 , and later, 270,000 . Grawitz mentioned a case with enlarged glands becoming softer during the attacks of fever, negative blood cultures, and no bacteria in the glands at autopsy. Janz extirpated the spleen in a case reported as pseudoleukemia; streptococci were found in many glands and tubercle bacilli in one supraclavicular gland. Fischer, ${ }^{11}$ reporting 12 cases of Hodgkin's disease, in which cultures from the blood and glands were negative, mentioned one instance with periodic fever in which organisms were found in the blood during the pyrexia, but not in the intervals. Laache ${ }^{18}$ saw .Hodgkin's disease with alternating pyrexia, and noted decrease in size of the glands during the fever and increase in the apyretic intervals. He mentions that Fiedler reported recovery in a case of Hodgkin's with recurrent fever. The communications of Van der Scheer, ${ }^{10}$ Barbrock, ${ }^{20}$ Kissel, ${ }^{21}$ Westphal, Verdelli, ${ }^{20}$ Freudweiler," likewise deal with Hodgkin's disease or "pseudoleukemia," as do recent artcles by Hirschfelder ${ }^{24}$ and Clarke, Stoll, ${ }^{25}$ Ruffin, ${ }^{20}$ and Tschistowitsch."

Shortly after Ebstein's paper it was shown that "chronisches Rüchfallsfieber" might occur as a striking symptom of malignant disease. Renvers ${ }^{\mathbf{3}}$ reported lymphosarcoma of the retroperitoneal glands, liver, and spleen, marked clinically by recurrent pyrexia in seven periods of seven days each. In Voelcker's $s^{99}$ case, with typical undulant fever, there was a sarcoma of the lumbar spine and retroperitoneal glands. Hanser ${ }^{30}$ reported ten cycles of fever with an epigastric tumor regarded as sarcoma. In Hewelke'st case of retroperitoneal lymphosarcoma, staphylococci were found four times in blood cultures taken during both febrile and afebrile stages. Multiple myelomas were found as the cause of fever recurring at

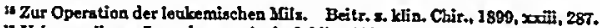

17 Ueber malignes Lymphom. Arch, 6. klin, Chic., $1897,17,167$.

in Ebstein und Schwalbe's Handhuch, $i, 8,84$.

14 Fan goval van psettdoleukemio med gedeeltelyk recurrend zoorstype, Neederl. Weekblate. 1890.

a Ueber Pseudoloukemio mit intercurriendem Fieberverlauf. Virchow und Hirach's Jahresberichte, 1890, it, 331.

a Meliga Neubildungen und chronisches Ruckfallsfieber, Vratechn 1805, No. 35; Drei

Facille von Hodglisischer Krankheic bei Kindera Vratech, 1805, 651.

2 Arehivo italiaso di clinies medics, 1805.

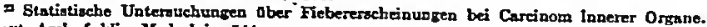
Deut. Areb. f. klin. Mred., Lriv, 544.

I' A Caso of Hodgkin's Divesse with Chronic Ilecurrent Fever. Oceidental Mred. Jour., 1904, xviii, 11 .

I A Case of Hodgkin's Disense with Slight Enisrgement of Peripheral Glands. Mled. Record, 1905, p. 773 .

\# Hodgkin's Disense. A Study of a Caso with Relapsine Fever. Axrr, Jour. Mrd. Scr. 1906, p. 557.

2 Ueber Paeudaleukemie mit periodiectien Fieber. Deut. med. Woch., 1907, 502. 753.

Ueber Lymphosarkamatos mit recurriendem Fieberveriauf. Deut. med. Woch., 1888.

Weber Sarkom mit recurriendem Fieberverisut. Berl klin. Woch, 1889, 796.

5) Ein Fall von chronischem ROckfallsfieber. Berl. klin. Woch.. 1889, 692.

it Lymphomatosis retroperitonealie maligns eum fehro recurrente Kronika lekarska, 1889, xii. 
intervals of one to twelve days over a period of nine months in a ease reconded by Hammer. ${ }^{2}$ Subohn" reported a questionable instance of recurrent fever with lymphosarcoma of the thymus, and Witthauer" noted periodic fever through five months in a roundcell sarcoma of the posterior mediastinum. Kast, beside the 2 cases mentioned above, described recurrent fever in a sarcoma of the hip and retroperitoneal glands occurring in a boy of sixteen. Tbe papers of Puritz, ${ }^{\text {s }}$ Bulubasch, ${ }^{\text {st }}$ Kissel, Glneser, ${ }^{\text {, }}$ Hobenemser, deal also with the associntion of altemating pyrexia and sarcoma. Hampeln," Anker," Kobler, ${ }^{\circ}$ Kast and Freundweiler write of its occurrence with carcinoma.

Delafield $^{41}$, and a little later Askanazy ${ }^{42}$, first called general attention to the similarity of many cases of tuberculosis of the lympbatic system and Hodgkin's disense. Musser's 2 cases of recurrent fever were tuberculous. In Xo. 8 of Sternberg's" series, this type of fever wns noted, but the cases should be classed as Hodghin's discase with terminal tuberculous infection. Schur's reported a combination of Hodgkin's disease and tuberculosis, with alternating pyrexis and a polynuclear leukocytosis of 30,000 . Crowder described a case of generalized tuberculosis with irregular fever, a leukocytosis of 19,000 , and the clinical pieture of Hodgkin's disease; tubercle bacilli and staphylococci were found in the glands nt autopsy. Strauss" saw a female patient with enlarged cervical glands and chronic recurrent ferer. At one time there was such a marked lymphocytosis as to suggest lymphatic leukcmia, but tuberculous glands were found at operation.

n Primlro markamstoso Oatitis mit eluronisebem nockfallabeber. Virchow Arch., 1804, 137, 280.

"' Jakrbuch der Hemburger Stastakrankenanstalten Ieipriz. 1502. 65.

4 Intermittrendes Fieber als Symptom eines Mediestinaltumon. Mloneh med. Wocli., 1001, 2024.

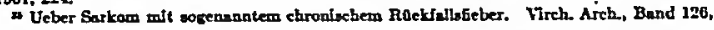
1312 .

* Sarkom der inneren LJmphdrites mit febril recurens. Medicingkoe obroeeme, IBO4, Hand 40-11, 601 .

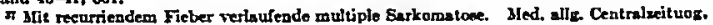
1807. C01.

a Zur Ssmptomatologie oceuleer visceraler Carcinome. Zeit. f. klin. Mted. viij, 2n1: Ueber iatermittireades Fieber im Verhuf des Magracarcinoms. Zeit. t. klin. Med., Band xiv. 560.

- Veber das Vorkommen intermittirendes Fieber bei ehroniwhen Krankbeiten. Inauk. Dim. Strussurr. 1800.

- Ueber 2 spinchea Fieber bei maligacn Nenbildungen dea Uncerteib. Wien. klin. Woch.. 1592. No. 23, 385; No. 24, 352.

4 A Case of Acute and Fatal Tuberculosis of the Lymphatio Glands. Mled. Reeord, 1887.

a Tuberevilos Iymphomo unter dem Bildo febriler Paendaleukemie veriaufend. Ziegler'"

Beit. 18s8, iil, 413.

4 Note oo the Fover of Ilodelin's Disease. Amer. Med., 1002, Iü. 13.

a Ueber eine eigenartige water dem Bilde der Peudaleukemie verlaulende Tubereulose des lymphatischen Apparta. Zeit. 1. Heilkunde, zix. 21.

- Zur Symptamatalozio der unter dem Bildo der Poudoleukemio verlaúfenden Lymphdruesentuberkuloese. Wien. klin. Woch. 1002.

* Sarcomatoso und lymphatiecbe Leukemie. Char. Antaleo, xxiii, 343. 
Although resting on diff rent pathological bases, the clinical features of all these cases are strik ngly similar. Febrile periods of from three to seven or ten days alternate with afehrile intervals of the same or slightly longer duration. As the disease progresses, the febrile periods usunlly lengthen, and continued fever of a remi tent type may be present for weeks or months. The last attack in the case here reported was of seventy-six days' duration. The temperature usually rises and falls slowly, hut there may he an abrupt rise with or without chill. Sweating is not uncommon. In the intervals between the first few febrile attacks the patients may feel and look perfectly well, hut wenkness, anemia, and cachexia gradually appenr. Fever is frequently the fist symptom. The onset may be sudden, as in one of Pel's cases. Pain in the abdomen, as an early symptom, was noted by Ebstein, Hanser, and Voclckers. It occurred in three distinct attacks in the case here described. In Hammer's case of multiple myelomas, pain in the chest was the first symptom. A patient of Musser had severe pain in the right inguinal region with each pyrexial attack.

Pel, Ebstein, Bulubasch, Klein, and Tschistowitsch described yellowish discoloration of the skin with patchy, hrownish pigmentation. Terminal icterus was noted by Pel, Ebstein, Musser, and Klein. Enlargment of the peripheral glands was absent in not a few cases (Pel, Ebstein, Renvers, Barbrock, Voelckers, Hanser, Tschistowitscb). The retroperitoneal and bronchial glands are more frequently involved. Ahsence of splenic tumor is not recorded in any case, except the one here noted. Spleen, liver, and palpable glands nently always incrense in size during the periods of fever, and frequently become tender. Laache noted a swelling of the glands in the afebrile periods and decrease of size with pyrexia.

The urine showed no characteristic changes. Albumin was infrequent, urobilin and bile pigment were occasionally noted. Diazo renction was noted by Renvers, Stoll, and in my case. Examination of the blood helps in the diagnosis chielly by ruling out other causes of fever. Secondary anemia becomes marked as the disease progresses. Stoll recorded a count of $1,700,000$ red cells and 30 per cent. hemoglobin. Leukopenia is more common than leukocytosis. Polynuclear leukocytosis would spenk more for tuberculous lymphomas than for Hodgkin's disease or lymphosarcoma: Strauss, however, noted a marked lymphocytosis in a tulsereulous case, and a leukocytosis of 270,000 was recorded by Kast in a boy of scren. Relative increase of the large mononuclear cells has been described in several instances. It must be remembered, in differentiating from septic affections, that positive hlood cultures have occusionally been reported. Positive or suggestive evidence of syphilis was found hy Pel, Klein, Renvers, Voelckers, Tschistowitsch and myself. In 27 instances in which sex was recorded, there were 16 males and 11 females. Recorded ages rok 134. No. 5.-NorExnE, 1907. 
varied from six to fifty-nine years. It is interesting to note that a number of patients had travelled extensively in the tropics. Recovery was noted in hut 2 cases. Laache mentions a report by Fiedler, and Tschistomitsch observed prompt eure under iodide after many other drugs had been tried for months. Denth has occurred in all other cises, usually from exhaustion.

Recurrent attacks of fever mny occur over long periods of time in many other conditions, and differential diagnosis is by no means always easy. - Repeated relapses in typhoid fercr will not often give difficulty; blood cultures will help in the cases in wbich Widal reaction is absent or long delayed. Claisse" has lately written on typhoid fever with numerous relapses. In my opinion, great hesitation should attend the diagnosis of sporadic cases of Maltn fever. Piroplasmosis should he considered in all çases of continued fever from the tropics, and examinations made from splenic punctures if necessary.

Hampeln was the first strongly to emplasize the occurrence of fever in carcinoma. The papers of Kraussold and Max Freudweiler are more recent. Fever may be an early syinptom; in a case of Hampeln there was fever for three montlss before a diagnosis wis made: Continued fever is rare, and the remittent, intermittent, or hectic type the most common. Periolic attacks may be noted and ague-like paroxysms of chills, fever, and swenting. In 475 cases of carcinoma collected by Freudweilcr temperature over $35^{\circ} \mathrm{C}$. was present in 24.6 per cent. 'The carcinoma may cause fever even without ulcerntion: in 14 out of 64 cases reported by Freudweiler there was no ulceration.

Heubner's mentions fever recurring in eight periods during the fall and winter in a ehild of four. At first there were only general symptoms during the febrile attacks, but later pus appeared in the urine, and the diagnosis of pyelitis nas assured. 'The frequency of pyelitis both in ebildren and adults needs constant cinphasis. It must be remembered also that renal calculi may nurely give rise to recurrent paroxysms of chills, ferer, and swenting without any urinary signs; the attacks are similar to those of intermittent hepatic fever. The attacks may occur, first, in tuberculons prelitis; second, in calculous pyelitis; and, thirl, in rare instances of stone in the pelvis, without ehronic suppurative pyclitis." (Osler. $^{\text {(o }}$

\footnotetext{
"Fievre typhoide nroloagie arec rechutes mutiples. Bull. et. mm. Soc. med. des Ifop. de Paris. 1006, xxiti. p. 571-574.

a Leber langdauergde Fieberzustende calkaren Ureprungs, Deut. Arch. f. klin. Mled. lxlv., 35.

- On Fover of Hepatic Origin, Particularly the Intermittent Pyrexin Associnted with Gallstones. Johny Hopkins Hoop. Rejourt, vol, ii, p. 1.

Some jearn ano a woman nged forty-five yearm was under obecration for recument ferer of a jears' dumtion. With periollic temperature, there would be occuxionsl elills and
} 
Romberg ${ }^{30}$ mentions 2 cases with ancmia, enlargement of the spleen and tiver, and fever of months' duration-in 1 case of continued type; in the other with apyrexial intervals of weeks' duration. A mitral murmur was interpreted as of functional origin, and both cases went to autopsy with a diagnosis of Hodgkin's disease. The postmortem revenled malignant endocarditis. Fever and progressive weakness and anemia may be the only symptoms of infective endocarditis. There may be apyretic intervals of days and weeks at a time. The interpretation of heart murmurs in cases with high temperature and anemia is, as Bloch ${ }^{\text {s1 }}$ has pointed out, often peculiarly difficult. Infective endocanditis grafted upon an old valvular lesion may run an extremely chronic course, over a year (Dreschfeld), thirteen months (Osier), and fifteen months (Romberg). Cases under my observartion with autopsy verification have lasted six, fifteen, and eighteen months. With absence of signs of heart involvement, diagnosis of the condition may, be difficult or impossible. Cases of this kind have recently been reported by Coles2 and Bramwell.s3 In chronic cases, leukocytosis may not occur; repeated counts in a case lasting fifteen months showed a leukopenia of 3000 to 5000 , with a relative lymphocytosis. Ewing" bolds that "Ieukocytosis is present probably in all cases, but is often intermittent, and single observations may fail to discover it." There is frequently a decided incrense in the polynuclear count after a chill, and abrupt rise of temperature. Blood cultures are of great help in diagnosis.

Frequent mention has been made of intermittent hépatic fever. Pain in the region of the liver and jaundice deepening after paroxysms of chill and fever usually make diagnosis reasonably ccrtain. In a case seen some years ago there was no jaundice until eight months after fever was noted. The increase of leukocytes, after chill and fever, as described by Pick has been twice observed. Pain and jaundice may be absent, and the temperature curve the only chancteristic fenture. Frerichs has described long-continued intermittent fever with stone in the hepatic duct, and Schmitz reported 2 cases of recurrent attacks of intermittent

\footnotetext{
swents, nnd compldint of dull aching in the right hypochondrium and lumbar repions. Iepkocytes were normal in apyretic intervals, hut after a chill and nbrupt rise of temperature, there tas meveral times noted a polynuclear leukocytosis of 28,000 to 36,000 . There was n history of liemnturin some years before, hue the urine never contained albumin, blood ar more than a few leukneytes. Operation revealed $n$ largo mono in tho pelvis of the right kidney with $n$ eaturrhal pyclitis, no eomplete hlocking of the ureter and no pyelonephritis. The fever with intermittent pyonephrosis (especinlly in tnbetica) is, in my-experienee; frequently
misinterpreted. w Krankheiten der Kreislnufsorgane. Ebstein und Schwalbe, Handbuel der Praktischen
Sledixin. $i$, 685 .

" Ueber Blutkrankheiten uniter dem nilde der nkuten Endocarditis. Deut. racd. Woch.,
00, , 512 . $1003,512$.

42 Johns IToplains Hoon. Bull,; xï̈, p. 252.

s" Clin. Studies, Edit.., 1005-1806, n.s. iv. p. 103-207.

H Cinical Patholoxy of the Blood, p. 300 .
} 
pyrexia without pain or jaundice, in which cessation of fever followed passage of gallstones.

Many interesting papers of late hnve dealt with fever in visceral syphilis. Janeways presented a communication on "Fever in Tertiary Syphilis" to this society in 1898 . Riede ${ }^{30}$ cites remarkable cases in his artiele "Ueber die fieberhnft veraufende Lues der Gallenblase, Gallengänge, sowie der Leber," and quotes "den alten Sutz, dass man bei unklaren fieberhaften Krankheiten immer zuerst an Tuberculose, so dann an Lues, endlich an Aktinomykose denken soll." F. Kemperes' reports several cases of syphilis of the liver with fever; in 1 case there was alternation of pyrevia with afebrile intervals over a period of a year. Recent literature on the subject is given in the srticles of Klemperer and Raubitschek.s"

In the past year Gilman Thompson called attention to the similarity between some cases of exophthalmic goitre and infective endocnrditis. Two years ago an army captain was under my observation for some months. The chief complaint was of weakness, irritahility, with ocensional attacks of diarrhoea, chills, fever, and sweating. There was cachexia, a mitral systolic murmur, a pulse of 120 to 140 , and irregular temperature recurring at intervals of days or weeks. The case was regarded as one of malignant endocarditis, until tremor, the general nervous picture, and Graefe and Stellweg signs decided for Parry's disense, even with absence of exophthalmos and goitre. A goitre developed later, and an operation by Dr. Halsted led to great improvement.

It is not uncommon to see children or young adults with longcontinued or, more rarely, recurrent pyrexia, dependent upon tuberculosis of medinstinal, mesenteric, or retroperitonenl glands. A boy of eight was seen a year ago who had had moderate fever almost daily for six months. There was a history of pertussis one year before and examination showed enlarged bronchial glands. A young woman, seen four years since, had, as chief complaint, pain in the lumbar spine and in both loins. There was recurrent pyrexia of moderate degree over a period of eight months without satisfactory explanation. A radiogram showed the spine normal, but gave the shndows of several calcified retroperitoneal glands.

In a remarkahle case, seen three years ago, a young woman of tuberculous family, had had recursent pyrexia for over twelve years. Fever recurred two or three times in one year, and again not for two or three years. There were no symptoms during the attacks beyond prostration and temperature of $103^{\circ}$

\footnotetext{
" Fever in Terting 8yphili. Trans, Awoc Amer. Phyz., 2898.

4 Ueber die fieberhnft veriaufendo Luen der Gallenblase, Gallengage, eowie der Ieber. Mittheil. aus den Grens, ri. 1.

* Ueber Fieber bei Syphiti der Ieber. Deut Zét f. k Med., lv, 176.

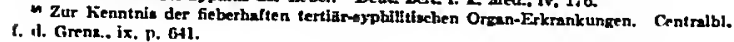


to $105^{\circ}$ for two or three weeks. During sereral attacks the cervical glands had enlarged and, when personally seen, there was evidence of bronchial gland enlargement. The liver and spleen were not palpable and the blood count was normal. Death occurred two years later from puerperal infection, but, unfortunately, no autopsy was obtained.

As seen above, alternating pyrevia may be a symptom of many very different condititons. Regularly repeated attacks over long periods of time are most suggestive of tuberculous lymphomas, Iodgkin's disease, lymphosarcoma or other varieties of sarcoma. In any recurrent pyrexia, the possibility of disease of deep glands should be remembered. Rarely, as in the case recorded by Rolleston, or in the onc hore described, the bver may be, clinically, the solc organ affected.

\title{
TRUE IFTESTINAL DXSPEPSLA.'
}

\author{
Br Mix Entrons, M.D.,

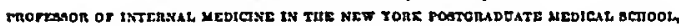 \\ NEW YORE.
}

Br the expression "intestinal dy'spepsia" in which the digestive function of the intestinal tract is disturbed: 'The idea of testing the functions of the intestines in a manner similar to those of the stomach prevailed among clinicians for a long while, but its execution was attended with great difficulties. To Adolf Sclimidt belongs the credit of having elaborated a method to that effect. This well-known clinician introduced the test diet, known under his name, for the purpose of examining the feces. By means of this method, Schmidt and Strasburger' were enabled to discover a group of cases of intestinal dyspepsia, in which the starch digestion is particularly disturbed. They designated it fermentative dyspepsia.

Sclimidt lias recently described the occurrence of functional achylin of the pancreas; by this he understands cases in whicl there is a malassimilation of the food, and a temporary lack of nuclear digestion-assigned by him as characteristic of the pancreatic secretion.

In a former papers I have described similar cases, in which all nutritive substances were poorly digested. Yct I hardly believe it advisable to spenk of achylia of the pancreas, because by achylia

\footnotetext{
1 Read at a meeting of tho American Gastro-nterological Association, at Atlantic City. N. J.. June 3, 1907.

I The Test Diet in Intestinal Disenses. Translnted by Charles D. Anron, Philndelphin, 1900.

Deut. Arch, f, klin. Med., 1901, lijx, 570 .

- Functionelle Pankreasachylic, Deut. Areh. I. kin. Med. 1906, Lextii, 150.

- Further Remarks oa the Digestive Bead Test for Ascertaining the Functions of the Dicestive Apparatus. Jour. Amer. Ifed. Assoe, Febrary 2. 1007.
} 